\title{
How robust is the cassiterite
}

\section{U-Pb geochronometer?}

LEONID A. NEYMARK ${ }^{1}$, RICHARD J. MOSCATI ${ }^{2}$, ANATOLY M. LARIN ${ }^{3}$, JOHN F. SLACK ${ }^{4}$

${ }^{1}$ U.S. Geological Survey, Denver, USA, 1neymark@usgs.gov

2U.S.G.S., Denver, USA, rmoscati@usgs.gov

${ }^{3}$ Institute of Precambrian Geology and Geochronology, RAS, St. Petersburg, Russia, larin7250@mail.ru

${ }^{4}$ U.S.G.S., Reston, USA, jfslack@usgs.gov

Cassiterite $\left(\mathrm{SnO}_{2}\right)$ is increasingly used for U-Pb dating of tin mineralization. In situ analysis by LA-ICPMS is the preferred analytical method because (1) complete digestion of cassiterite needed for ID-TIMS dating is extremely difficult, and (2) cassiterite typically has low U contents making SIMS analysis problematic. The recently developed HBr-based digestion technique (Tapster and Bright, 2020; Carr et al., 2020) allows reliable ID-TIMS characterization of matrixmatched cassiterite reference materials useful for LA-ICPMS geochronology. By comparing in situ data with the ID-TIMS results, we estimate accuracy and precision of cassiterite U$\mathrm{Pb}$ ages for our LA-ICPMS analyses at about 1.5\% (2SD), based on long-term reproducibility of an $\sim 155 \mathrm{Ma}$ internal secondary cassiterite matrix-matched reference material.

Cassiterite is found not only in tin and rare metal ore deposits, but also as an accessory phase in "tin granites". Additionally, cassiterite may be the only suitable phase for direct $\mathrm{U}-\mathrm{Pb}$ dating of mineralization in some VMS and SEDEX base-metal deposits.

In this talk we discuss newly discovered issues with cassiterite $\mathrm{U}-\mathrm{Pb}$ dating that include the occurrence of inheritance (Paleoproterozoic $\sim 1.85$ Ga cassiterite in the Neoproterozoic $\sim 720$ Ma Yazov granite, Baikal Region, Russia), and cassiterite dissolution/reprecipitation processes (in the $\sim 1.48$ Ga metamorphosed Sullivan SEDEX Pb-Zn-Ag deposit, British Columbia, Canada).

References

S. Tapster, and J.W.G. Bright, 2020. Geochronology

P.A. Carr et al., 2020. Chemical Geology 